\title{
本草考古：本草学与考古学的交叉新领域
}

彭华胜 ${ }^{1,2}$, 袁媛 ${ }^{2}$, 黄璐琦 ${ }^{2 *}$

1. 安徽中医药大学药学院, 合肥 230012 ;

2. 中国中医科学院中药资源中心, 道地药材国家重点实验室培育基地, 北京 100700

* 联系人, E-mail: huangluqi01@ 126.com

2018-02-27 收稿, 2018-04-12 修回, 2018-04-13 接受, 2018-05-03 网络版发表

名贵中药资源可持续利用能力建设项目 (2060302)资助

摘要随着20世纪考古学的兴起, 大量的药物或药物相关遗迹(遗存)相继出土, 为开展本草的考古研究提供了 有利条件, 进而为本草考古的建立奠定了基础. 本文从本草考古的形成基础、定义与学科定位、研究对象、研究 方向以及与其他考古学科的关系等多个方面对本草考古这一新兴学科领域进行了阐述. 本草考古, 即应用现代考 古理论与方法, 以考古出土的药物及其相关遗存为对象, 探索人类与药物的相互关系, 重建中医药文化遗存的时 空框架及中医药发展历史, 为本草研究提供了新的途径. 本草考古为考古学与本草学的交叉新领域, 拥有广阔的 发展前景, 目前研究仍处于起步阶段, 需借助其他考古学科研究成果, 积极推动该领域的进步与发展.

关键词本草考古, 本草学, 考古学, 交叉领域

人类的生存与繁衍与医药学息息相关. 史前的 先民, 在生存与繁衍过程中, 逐渐地认识并应用了药 物. 中国医药学的历史源远流长, 可以追溯到遥远的 古代. 古代文献中有大量关于药物起源与应用的传 说, 如“神农尝百草”等. 人类的生命与生活离不开药 物, 因此, 一些药物、药物用具、医药文书等在考古 遗址中保存下来.

丰富的地下医药文物是考古学的重要内容. 随 着考古发现的日益丰富和现代科学技术的发展, 尤 其是随着中医药的发展, 人们对古代本草的研究更 加迫切, 本草中蕴含的历史、药物基原以及应用知识 急需深人研究与继承. 为了复原古代药物应用的历 史与文化, 必然要求对古代药物开展深人系统研究. 因此, 对考古出土古代药物遗存的研究应运而生. 考 古的分支学科多以特定时代或研究对象而命名, 如 新石器时代考古、夏商周考古、秦汉考古、唐宋考古、 农业考古、疾病考古等. 因此, 考古遗址中出土与药
物有关的考古, 可统称为药物考古. 中国特色的传统 药物学在古代称为“本草”, 寓意“以草为本”, 因此中 国的药物考古又可称为“本草考古”.

\section{1 本草考古的形成基础}

中医药起源是医学史的一个重要科学问题. 中 国古代典籍, 很早就有“神农尝百草”“药食同源”“医 药同源”等记载, 但由于缺乏实物证据, 迄今无法回 答本草起源等科学问题. 自 20 世纪初以来, 随着考古 学的兴起, 一批涉及医药的重要遗迹和遗存相继被 发现, 如河南安阳殷墟甲骨文字 ${ }^{[1]}$ 、湖南长沙马王堆 汉墓出土大量的药物遗存 ${ }^{[2,3]}$ 、河北满城刘胜墓出土 的药用器具 ${ }^{[4]}$ 、孟县城西韩庄岭出土的汉代太医药 罐 $^{[5]}$ 、陕西西安南郊何家村唐邠王府遗址中出土的多 种贵重药材和数十件医药器具 ${ }^{[6]}$ 、福建泉州海船出土 的宋代进口香料药物 ${ }^{[7]}$ 等. 其中, 汉代黄褐釉药碾是 迄今最早的药用瓷器 ${ }^{[8]}$, “医工铜盆”是迄今最早有医 
药铭文的器皿 ${ }^{[4]}$. 河北晋县唐墓出土的药碾与中草药 同处一室 ${ }^{[9]}$. 这些药物遗存中, 有药物器具, 有医药 壁画, 有帛书竹简, 有各类药材香药, 甚至有中成药 和丹药, 可谓种类繁多, 琳琅满目.

各个历史时期药物及药物相关遗存丰富多彩, 展现了我国中医药文化的源远流长和博大精深, 引 起了学者们的高度关注和重视. 1936年, 我国医史学 家王吉民首开医学文物与文献的征集之先河, 倡议 筹办医史博物馆; 1938年中华医学会医史博物馆正式 成立 ${ }^{[8]} .20$ 世纪60 70年代, 我国考古界对河北满城 汉墓、甘肃武威汉墓、长沙马王堆汉墓等进行发掘, 先后出土了一批重要医药文物, 吸引了考古学、医 学、历史学等领域的诸多学者开展药物考古的研究, 推动了对医药文物的重视 ${ }^{[10]}$. 1983 年, 戴应新对 1949 1981年期间考古发现的医药资料进行了详细论 述 $^{[11]}$. 1984年, 《中医年鉴》刊《新中国出土医药文 物的研究》; 1989年，《建国40年中医药科技成就》 中刊载《中医考古及出土文物研究》 ${ }^{[12]}$. 据和中浚和 吴鸿洲 ${ }^{[8]} 2001$ 年统计, 全国中医药院校共建立了19家 医史博物馆或医史陈列馆, 成为我国高校专业陈列 馆中数量最多的一个门类. 近年来, 《中国医学通史 (文物图谱卷) 》 ${ }^{[13]}(2000$ 年) 、《中华医学文物图 集》 ${ }^{[8]}(2001$ 年)、《“一带一路” 中医药文物图谱 集》 ${ }^{[14]}$ (2016年)、《中国药学文物图集》 ${ }^{[15]}$ (2017年) 等相继出版. “医学考古学”或 “医学考古”, 呼之欲 出 ${ }^{[10,16]}$. 20世纪20年代以来, 田野考古学在中国的兴 起, 尤其是史前文化遗址的发掘, 为中医药起源研究 提供了考古学证据. 科学问题的提出以及大量遗存 的发现, 均为本草考古的形成奠定了坚实而深厚的 基础.

\section{2 本草考古的定义与定位}

\section{1 本草考古的定义}

本草考古是以考古出土的药物或药物相关遗存 为研究对象, 应用现代科技方法和技术, 探求人类利 用药物的信息, 探索古代先民与药物的相互关系, 复 原和重建人类利用药物的历史. 考古出土的药物或 药物相关遗存主要包括药物、药物用具、医药文书等.

本草考古的内涵是运用现代多学科技术和方法, 围绕本草的起源、本草的发展和本草的应用等进程, 厘清古代药物的基原、药物的药用部位、采收、加工、
炮制以及服用、应用等.

本草考古的外延涉及以药用或健康需求为目的 的药物、器具与制度等考古研究, 如药食两用、保健 器材、药具、药物计量工具、药品经营的文书与制度、 本草学家等. 因此, 从广义上讲, 本草考古复原古代 药物及其相关领域的文化历史，重建药物使用的生 活方式, 复原药物文化发展进程.

\section{2 本草考古的定位}

本草考古是根据古代人类活动遗留下来的物质 资料，阐述古代人类对于药物的认知与利用以及与 药物相关实践的历史，在一定程度上重建古代药物 利用的历史. 本草考古是传统药物学与考古学交叉 融合形成的领域, 具有本草学与考古学双重性质与 学科基础. 从考古角度出发, 本草考古研究考古调查 发掘所获的有关药物的遗迹、遗物, 复原中国中医药 文化历史, 复原中医药文化发展进程. 从本草学角度 出发, 本草考古研究本草发展进程与历史, 确定古代 药物的基原, 揭示药物的起源和发展、药物的形成和 变迁以及药物生产过程的规律, 推动本草事业的传 承与发展，增强中医药文化认同与自信.

\section{3 本草考古的研究对象}

本草考古, 其对象是出土的药物及药物相关的 遗存. 考古发掘的药物遗存, 包括植物药、动物药和 矿物药; 包括单味药, 也包括复方; 包括药材, 也包 括成药制剂; 包括生药, 也包括炮制加工品. 其中, 植物药遗存主要指植物大遗存, 如根、茎、叶、果实 和种子等.

需要说明的是, 本草考古中所指的药物是广义 的.中国古代有“药食同源”一说，因此还包括药食两 用的品种. 除此之外, 香薰、洗浴所用可以防病、治 病的品种, 都可属于本草考古的范畴. 此外, 保健器 材、药具、药物计量工具、医药文书等遗迹, 以及遗 址中反映药品经营的文书等也都可属于本草考古的 范畴.

\section{4 本草考古的研究方向}

本草考古是对考古出土的医药相关各种遗存研 究的一个领域, 它们共同的目标均是认识和了解古 代人类与预防疾病、治疗疾病的历史，包括药物的利 用，进而阐述人类医药文化的发展过程. 具体而言, 
本草考古的目的是寻找人类发现、利用药物的信息, 探索古代人类与药物的相互关系, 认识使用药物的 进程, 重建人类使用药物的历史. 简而言之, 本草考 古即以本草 (中国古代药物学)为载体重建中医药文 化遗存的时空框架和重建中医药的历史.

\section{1 药物起源}

中医药起源是医药史中一个重要的课题. 仰韶 文化和龙山文化遗址中出土的大量骨针, 被认为与 针尒起源有关 ${ }^{[17]}$. 早期的医药典籍虽有“神农尝百 草”“药食同源”等记载, 但是药物的起源依然期待实 物证据. 考古学尤其是史前考古为药物起源提供了 新的契机 ${ }^{[18]}$. 尤其是植物考古学发现一些遗址出土 了丰富多样的药用植物 ${ }^{[19]}$. 早期的文化遗址中出土 的与药物相关的遗存, 都是后来录人本草典籍的常 用中药, 如河姆渡遗址中出土的穿山甲与芚实 ${ }^{[20]}$, 河北㩰城台西村商代房址中出土的郁李仁和桃仁 ${ }^{[21]}$. 无论当时是否作为药用, 至少值得高度关注. 这些早 期的植物或药材遗存为揭示药物起源提供了宝贵的 资料.

开展中国的药物起源研究, 应以史前考古至最 早的本草著作《神农本草经》成书这段历史为重点. 药物起源研究, 不仅是单味药的发现与应用历史, 而 且包括中药炮制、中药制剂、复方应用, 以及药物的 栽培与驯化起源等.

\section{2 药物的正本清源}

宋代《本草衍义》序云: “疾病所可凭者医也, 医 可据者方也, 方可恃者药也.” 由此, 中医处方用药, 最终落实到药上. 然而, 古往今来, 药物的基原常发 生变迁. 药物的正本清源研究旨在揭示古代药物的 基原, 复原古代中医药学家用药的品种. 为探明古代 药材的基原, 很多学者利用本草文献开展了深人的 本草考证研究. 但是, 要复原古代药物基原, 最重要 的依据就是出土的药物遗存.

长沙马王堆一号汉墓出土的 9 种药材是我国迄今 发现保存最好的药物标本 ${ }^{[22]}$, 其中桂、花椒、杜德、 辛夷等均载于《神农本草经》. 长沙马王堆三号汉墓 出土的《五十二病方》是目前最早的方书, 记录了 283 个方剂, 有 250 多种药物 ${ }^{[23]}$, 其中三分之一见于后代 的《神农本草经》. 长沙马王堆三号汉墓一并出土的 也有九种药材 ${ }^{[2,3]}$. 广西汉墓出土的药物有金银花、
姜、铁冬青、大麻、柏叶等 ${ }^{[24 ~ 27]}$. 西安南郊何家村唐 邠王府遗址出土了很多贵重药材, 如丹砂、钟乳石、 紫石英、白石英、琥珀等 ${ }^{[28]}$. 药盒内的唐人题记将丹 砂分别分为 7 级: 井砂、光明碎红砂、光明紫砂、大 粒光明砂、次光明砂、红光丹砂和朱砂. 实物确有朱 紫明暗、大小与精粗等差异 ${ }^{[6,11]}$, 这是现存最早的药 材商品规格等级. 这些药材遗存为古代药材基原研 究提供了实物资料, 将为中药材的正本清源研究提 供有力的证据.

药物的研究, 需要将出土的药物与历代本草文 献考证相结合. 以汉代至清代期间为重点, 探明相应 历史时期药物的基原，主要技术手段包括性状鉴定、 显微鉴定、理化鉴定以及DNA分子鉴定.日本学者对 正仓院中保存的唐代药材开展了深人研究, 综合了 性状、显微与化学等多种方法, 为了解唐代药材基原 提供了依据 ${ }^{[29,30]}$.

\section{3 药材贸易}

《博物志》记载张骞出使西域, 带回红花、安石 榴等. 历代以来, 相继有很多国外品种成为中药材. 唐末五代《海药本草》则是一部外来药的专著. 云南 洱源县的火焰山砖塔(建于 1155 年)发现 30 种中药, 有 珍珠、干姜、荜菝、草果、槟榔、樟木子、荜澄茄、 胡椒、桃仁等 ${ }^{[31]}$. 洱源县当时隶属白族建立的“大理 国”. 这30种汉文题记的药材，反映了少数民族与汉 族之间的药材贸易 ${ }^{[11]}$.

新疆吐鲁番出土的晋唐文书, 记载成交的砧砂、 铪石、香料等数额较大, 如有人一次买香药 $286 \mathrm{~kg}^{[32]}$, 足见当时医药贸易之盛况. 1974年, 福建泉州湾宋代 沉船出土了大量药物, 共 $2350 \mathrm{~kg}$, 有降香、沉香、檀 香、胡椒、槟榔、乳香、龙涎、玳琩等, 这些香药是 宋代中外药材交流与贸易的实物证据 ${ }^{[7]}$.

药材贸易的研究, 需将出土的遗存与历代本草、 史志类文献相结合, 重点阐明相应历史时期药材贸 易，重建我国民族之间、我国与其他国家之间的药材 交流历史，确定药材基原，复原药材传播路线与 文化.

除上述药物起源、药物的正本清源以及药物贸易 外，本草考古还可以结合计量器物复原相应历史时 期古代方剂的药物计量; 也可以结合出土药简, 对药 物官吏体系、药物机构、药物供给、药物采购、常备 药物及检查等药物制度进行研究, 以复原古代药物 
制度 ${ }^{[33]}$.

\section{5 本草考古与对考古出土的医药相关各种 遗存研究的关系}

对考古出土的医药相关各种遗存研究, 其范围 比较广泛, 包括预防、卫生、保健、康复、治疗等很 多领域, 也包括体质人类学、古病理学等相关学科. 其中包括以考古出土的药物或药物相关遗存为研究 对象. 中医药是具有我国民族特色的医药学, 中医药 学则是我国医药考古的特色. 就中国古代治疗方法 而言, 包括药物疗法和非药物疗法, 后者包括气功、 针尒、手术、祝由等. 中国传统药物学称为本草, 因 此, 中国以考古出土的药物或药物相关遗存的研究 称为本草考古. 综上所述, 本草考古是对考古出土的 中国古代医药相关各种遗存研究的一个领域.

目前, 对考古出土的古代医药相关各种遗存研 究的相关领域进展不一. 其中, 古病理学已经成为一 门学科, 2010年我国出版了Charlotte Roberts和Keith Manchester合著的《疾病考古学》第三版的中文版, 书 中涉及到的疾病包括先天疾病、齿科疾病、创伤、关 节疾病、传染性疾病、新陈代谢和内分泌疾病、肿瘤 性疾病 ${ }^{[34]}$. 我国的古病理学研究发展迅速, 近年来 一些学者相继对出土人骨开展了古人口腔疾病、牙周 疾病等方面的研究 ${ }^{[34 ~ 40]}$, 对人类椎骨疾病 ${ }^{[41]}$ 、膝关 节 ${ }^{[42]}$ 、骨骼病变与骨骼创伤 ${ }^{[43]}$ 及体质人类学 ${ }^{[44,45]}$ 也 进行了相关研究.

“医药同源”, 本草学是中医药学的重要组成部 分. 中草药自古以来就是治疗疾病的重要手段之一. 随着药物分析技术的发展, 体内极微量的药物含量 测定已经得到广泛的应用, 头发中残留的痕量化学 物质甚至可以被检测或鉴定 ${ }^{[46]}$. 这为开展古人遗骸 中的药物残留物研究提供了技术支持. 本草考古对 出土的药物或药物相关遗存进行研究, 进而阐述古 代人类对药物的利用, 与疾病考古相互促进, 共同认 识和了解古代人类预防疾病、治疗疾病的历史, 推动 对考古出土的古代医药相关遗存的研究.

\section{6 本草考古与植物考古的关系}

植物考古学是专门研究考古出土植物遗存的学 科. 中国传统药物学称为 “本草”, 中国传统药物的主 体来自于植物药, 因此本草考古与植物考古的关系
非常密切. 两者的研究目的均与考古学一致, 即探讨 古代人类文化史, 复原古代人类生活方式, 解释人类 文化的发展与过程 ${ }^{[23]}$. 但是两者在研究对象、研究方 法以及阐述的问题上存在差异.

两者研究对象不同. 植物考古的研究对象是考 古遗址中出土的植物遗存. 本草考古的研究对象是 考古遗址中出土的药物或药物相关的遗存. 中国的 传统药物来源于植物、动物和矿物, 也有少数人工制 品, 如人工炼制的丹药. 虽然植物药占主体, 但还有 动物药、矿物药和人工制品. 植物考古所研究的植物 遗存可以分为与人类活动直接相关的植物遗存和间 接相关的植物遗存, 前者指食物、燃料、建筑材料等 被人类利用的植物，后者指影响人类社会生活形态 的自然植被 ${ }^{[20]}$. 从这个角度看, 本草考古中的植物 药无疑属于被人类利用的植物遗存, 而与人类活动 间接相关的植物遗存则不是本草考古的研究对 象. 即使是与人类活动直接相关的植物遗存, 也不 是所有的都与药物相关. 因此, 植物考古与本草考 古在研究对象上有一定交叉, 但不是包含与被包含 的关系.

判断出土的植物遗存在当时是否作为药物, 是 本草考古的关键. 只要是考古发现的植物遗存, 可属 于植物考古的范畴. 但是出土的植物遗存不一定都 与药物相关. 这需要根据出土的植物遗存及其所承 载的器血或遗址中其他遗存进行综合推断. 如长沙 马王堆一号汉墓、三号汉墓中出土了杜蘅、辛夷等多 种药材, 甚至遗址中一并出土的还有医书 ${ }^{[2,3,22]}$. 河 北满城西汉刘胜夫妇墓出土了多种医药器具, 其中 蒸药和制药用的铜盆在口沿和器身上铭刻“医工”字 样, 表明为医用器具 ${ }^{[4]}$. 西安何家村唐邠王府遗址出 土了 40 多件医药器血, 有炼丹器银石榴罐(即简单蒸 馏器)、温药器、研药器、盛药器等 ${ }^{[6]}$. 与遗址中的植 物遗存相比, 药材遗存的数量要少的多. 但是, 在历 史长河中药物器血的数量也不容小觑. 如和中浚对 出土的药用杵臼和謷药的温药器进行了梳理, 其中 温药器有中山靖王刘胜墓出土的铜釜、河南孟县韩庄 岭出土的陶质 “太医”铭记药罐、西安何家村出土的 “暖药”题记的金锅、宁波出土的唐代温药壶和宋代陶 药壶、明定陵出土的御药房金罐等, 另外仅汉代出土 的铜铁杵臼有 9 套之多 ${ }^{[47,48]}$.

植物考古与本草考古都属于科技考古, 因此, 植 物考古学的方法都可为本草考古所采用. 古代加工、 
败藏、应用药物过程中, 一些残留物可能残存或沉积 在相关遗存或遗迹上. 这些残留物有的肉眼可见, 如 液体、炭化物等, 有的为肉眼不可见的残留物, 如化 学成分、植硅体、淀粉粒等. 药物残留物分析技术是 本草考古的重要方法之一. 目前, 考古发掘出土的药 物残留物的种类丰富多样, 除单味药材或制品药物 外, 有的为残留在各种容器中的可见或不可见残留 物, 有的为残留在人类遗骸内的药物残留 ${ }^{[49]}$. 通过对 考古发掘出土的器物进行药物残留物分析, 应用相应 的提取分离和鉴定方法, 检测有机残留物的种类, 追 踪药物的动植物来源, 以此来研究药物的利用与发展 史, 以重建古代人类应用药物的历史 ${ }^{[50,51]}$.

\section{7 结语}

本草考古是系统研究考古出土药物或药物相关 遗存的新方向, 是考古学与本草学的交叉领域, 不仅 服务于考古学, 也是本草学的重要领域. 以考古发掘
中出土的药物或药物相关遗存为主要对象，应用现 代科技考古的理论和研究方法, 揭示人类发现和利 用药物的历史和规律, 探求考古药物中承载的信息, 认识和了解古代人类与药物的相互关系, 解释人类 医药文化的发展与进程的学科.

与本草考古类似的是农业考古. 1921年在仰韶文 化遗址中采集到石器工具及陶片上的稻壳印痕 ${ }^{[52]}$. 1972年, 河姆渡遗址的发现将中国水稻的栽培历史 追溯到距今 7000 年以前 ${ }^{[52]}$. 1981年, 陈文华先生创办 了《农业考古》杂志, 标志着“农业考古”在我国开始 形成 ${ }^{[53]}$. 中医药文化源远流长, 与中华文明一样灿 烂久远. 本草考古拥有广阔的学术舞台, 但目前依然 有很多处女地. 我国学者虽然在药物考古方面有很 多发现, 并开展了诸多探索和研究, 但客观上说, 这 些研究尚属于零星的初步阶段. 本草考古尚需要凝 聚力量, 锻炼队伍, 借助现代考古研究的成果, 共同 推动考古学与本草学的学科发展.

\section{参考文献}

1 Zhu F H. Study on oracle from Yin Dynasty ruins in nearly a hundred years (in Chinese). History Res, 1977, (1): 115-139 [朱风瀚. 近百 年来的殷墟甲骨文研究. 历史研究, 1977, (1): 115-139]

2 Liu L X. Study on unearthed drug identification of No. 3 tomb of Han Dynasty in Mawangdui, Changsha (in Chinese). Chin J Trad Chin Med Pharmacy, 1987, 2: 40-41 [刘丽仙. 长沙马王堆三号汉墓出土的药物. 中华中医药杂志, 1987, 2: 40-41]

3 Liu L X. Drugs unearthed from No. 3 tomb of Han Dynasty in Mawangdui, Changsha (in Chinese). Archaeology, 1989, (9): 856-860 [刘 丽仙. 长沙马王堆三号汉墓出土药物鉴定研究. 考古, 1989, (9): 856-860]

4 Zhong Y Y. Medical instruments unearthed from the tomb of Liu Sheng in the Western Han Dynasty (in Chinese). Archaeology, 1972, (3): 49-53 [钟依研. 西汉刘胜墓出土的医疗器具. 考古, 1972, (3): 49-53]

5 Shang Z M. Meng County in the Han Dynasty is the medicine pot (in Chinese). Cult Rel Cent China, 1985, (1): 13 [尚振明. 孟县出土汉 代太医药罐. 中原文物, 1985, (1): 13]

6 Writing Group of Shaanxi Provincial Museum. The development of medical and pharmacology in the Tang Dynasty from the medical relics unearthed in the southern suburbs of Xi' an (in Chinese). Cult Rel, 1972, (6): 52-55 [陕西省博物馆文管会写作小组. 从西安南郊 出土的医药文物看唐代医药学的发展. 文物, 1972, (6): 52-55]

7 Writing Group of Excavation Report in Song Dynasty Ships in Quanzhou Bay. A brief report on the excavation of the Song Dynasty ships in Quanzhou bay (in Chinese). Cult Rel, 1975, (10): 1-18 [泉州湾宋代海船发掘报告编写组. 泉州湾宋代海船发掘简报. 文物, 1975, (10): 1-18]

8 He Z J, Wu Z J. Atlas of Chinese medical relics (in Chinese). Chengdu: Sichuan People’s Publishing House, 2001 [和中浚，吴鸿洲。中 华医学文物图集. 成都: 四川人民出版社, 2001]

9 Shijiazhuang Regional Institute of Cultural Relics. Tang tomb in Jin County, Hebei (in Chinese). Archaeology, 1985, (2): 149-153 [石家 庄地区文物研究所. 河北晋县唐墓. 考古, 1985, (2): 149-153]

10 Gao Y Q. Study on medical archaeology (in Chinese). Chin Med Cul, 1997, (3): 24-27 [高毓秋. 试论医学考古学. 中医药文化, 1997, (3): 24-27]

11 Dai Y X. Study on the medical data of archaeological discoveries after liberation (in Chinese). Archaeology, 1983, (2): 180-186 [戴应 新. 解放后考古发现的医药资料考述. 考古, 1983, (2): 180-186]

12 State Administration of Traditional Chinese Medicine. The Scientific and Technological Achievements of Traditional Chinese Medicine in the Past 40 Years (in Chinese). Beijing: Ancient Books Publishing House of Tradional Chinese Medicine, 1989 [国家中医药管理局. 建国 40 年中医药科技成就. 北京: 中医古籍出版社, 1989] 
13 Fu W K, Li J W, Lin S G. A General History of Chinese Medicine (in Chinese). Beijing: People's Medical Publishing House, 2000 [傅维 康，李经纬，林昭庚. 中国医学通史(文物图谱卷). 北京：人民卫生出版社, 2000]

14 Cao H, Liao G. Cultural Relics Atlas of Chinese Medicine in "the Belt and Road" (in Chinese). Guangzhou: Jinan University Press, 2016 [曹晖, 廖果. “一带一路”中医药文物图谱集. 广州：暨南大学出版社, 2016]

15 Cao H, Liang J. Atlas of Chinese Pharmacy Cultural Relics (in Chinese). Guangzhou: Jinan University Press, 2017 [曹晖, 梁峻. 中国药 学文物图集. 广州: 暨南大学出版社, 2017]

16 He Z J. Medical archaeology and study of medical cultural relics (in Chinese). Chin Med Cul, 1999, (4): 27-29 [和中浚. 医学考古与医 文物研究. 中医药文化, 1999, (4): 27-29]

17 Chen D J. Study on describing the origin of acupuncture (in Chinese). J Nanjing Univ Trad Chin Med, 1984, (2): 50-52 [陈道谨. 试述 针尒的起源. 南京中医学院学报, 1984, (2): 50-52]

18 Zhao Y, Zhu J P, Yuan B, et al. Research on the origin of Chinese medicine based on the report of archaeological excavation (in Chinese). J Trad Chin Med, 2014, 55: 1415-1417 [赵艳, 朱建平, 袁冰, 等. 基于考古发掘报告的中医药起源相关文献研究. 中医杂志, 2014, 55: 1415-1417]

19 Zhao Z J. An overview of Plant Archaeology (in Chinese). Agric Archaeol, 1992, (1): 34-39 [赵志军. 植物考古学概述. 农业考古, 1992, (1): 34-39]

20 Zhu D M. The origin of Zhejiang medicine in the pre-Qin Period (in Chinese). J Zhejiang Chin Med Univ, 2008, 32: 705-708 [朱德明. 先秦时期浙江医药的起源. 浙江中医药大学学报, 2008, 32: 705-708]

21 Geng J T, Liu L. Taoren and Yuliren unearthed in the ruins of the Shang Dynasty in Gaocheng (in Chinese). Cult Rel, 1974, (8): 54-55 [耿鉴庭, 刘亮. 葍城商代遗址中出土的桃仁和郁李仁. 文物, 1974, (8): 54-55]

22 He Z C. Medicine unearthed from the No. 1 Han tomb in Mawangdui, Changsha (in Chinese). J Trad Chin Med, 1973, (2): 36, 42-43 [何 祚成. 长沙马王堆一号汉墓出土的药物. 中医杂志, 1973, (2): 36, 42-43]

23 Song J Z, Wu Z M. Discussion about that Prescriptions of Fifty-two Diseases is the earliest extant collection of prescription in China (in Chinese). J Hunan Univ Chin Med, 1984, (2): 56-59 [宋经中, 吴子明. 试论《五十二病方》是我国现存最早的一部验方集. 湖南中 医药大学学报, 1984, (2): 56-59]

24 Cultural Relic Team of Guangxi Zhuang Autonomous Region. A brief report on the excavation of the Han Dynasty tomb in Luobowan, Guangxi (in Chinese). Cult Rel, 1978, (9): 25-36 [广西壮族自治区文物工作队. 广西贵县罗泊湾一号墓发掘简报. 文物, 1978, (9): 25-36]

25 Cultural Relic Team of Guangxi Zhuang Autonomous Region. A brief report on the excavation of the Han Dynasty tomb in Hepu, Guangxi (in Chinese). The Cult Rel Coll, 1981, 4: 46-56 [广西壮族自治区文物工作队. 广西合浦堂排汉墓发掘简报. 文物资料丛刊, 1981, 4: 46-56]

26 Cultural Relic Team of Guangxi Zhuang Autonomous Region. The No. 2 tomb of Han Dynasty of Luobowan, Guangxi (in Chinese). Archaeol, 1982, (4): 355-364 [广西壮族自治区文物工作队. 广西贵县罗泊湾二号汉墓. 考古, 1982, (4): 355-364]

27 Huang Z Q. Cleaning the tomb of Han Dynasty of luobowan, Guangxi (in Chinese). Acta Archaeol Sin, 1957, (1): 155-162 [黄增庆. 广 西贵县汉墓的清理. 考古学报, 1957, (1): 155-162]

28 Revolutionary Writing Group of Shaanxi Provincial Museum. The cultural relics of kiln in the Tang Dynasty found in Hejia village from southern Xi' an (in Chinese). Cult Rel, 1972, (1): 30-42 [陕西省博物馆文管会革委会写作小组. 西安南郊何家村发现唐代窑藏文物. 文物, 1972, (1): 30-42]

29 Asahina T Y. Shosoin Drugs. Osaka: Plant Literature Journal Guild, 1955

30 Office of Shosoin in Imperial Household Agency. Legend of I Shosoin Drugs. Tokyo: Chuokoron Shinsha, 2000

31 Tian H Q, Huang D R. Dali series · archaeological cultural relics (in Chinese).Volume 6. Kunming:Yunnan National Publishing House, 2009 [田怀清，黄德荣. 大理丛书・考古文物篇. 第六卷. 昆明：云南民族出版社, 2009]

32 Cultural Relic Collation Group of Turpan. Summary documents unearthed in tombs of the Jin Dynasty and Tang Dynasty in Turpan (in Chinese). Cult Rel, 1977, (3): 21 [吐鲁番文物整理小组. 吐鲁番晋-唐墓葬出土文书概述. 文物, 1977, (3): 21]

33 Sun Q B. Study of the drug system in Dunhuang Bamboo Slips of Han Dynasty and Juyan Bamboo Slips of Han Dynasty (in Chinese). Western J Trad Chin Med, 2017, 30: 42-45 [孙其斌. 《敦煌汉简》与《居延汉简》医药简中的药物制度. 西部中医药, 2017, 30: 42-45]

34 Charlotte R, Keith M. The Archaeology of Disease (in Chinese). 3rd ed. Jinan: Shandong Pictorial Press, 2010 [夏洛特·罗伯茨，基思·曼 彻斯特. 疾病考古学. 第三版. 济南: 山东画报出版社, 2010]

35 Han Y X. Study on oral diseases of the human jaw bone unearthed in two thousand years ago (in Chinese). Master Dissertation. Xi'an: The Fourth Military Medical University, 2005 [韩迎星. 两千年前出土人领骨的口腔疾病研究. 硕士学位论文. 西安: 第四军医大 学, 2005]

36 Wang W, Zeng X L, Liu W. Analysis of periodontal disease in Chinese people in Xia Dynasty (in Chinese). J Peking Univ (Medical ed), 2007, 39: 511-514 [王巍, 曾祥龙, 刘武. 中国夏代人的牙周疾病状况分析. 北京大学学报(医学版), 2007, 39: 511-514] 
37 Meng Y, Shao J L, Li H T, et al. Caries study of human skull speciemens unearthed from ruins of Tang Dynasty in Xi'an (in Chinese). Chin J Stoma, 2008, 43: 686-688 [孟勇, 邵金陵, 李海涛, 等. 西安市唐代遗址出土人颖骨标本的齝病研究. 中华口腔医学杂志, 2008, 43: 686-688]

38 Meng Y, Zhang H Q, Pan F, et al. Prevalence of dental caries and tooth wear in a Neolithic population (6700-5600 years BP) from northern China. Arch Oral Biol, 2011, 56: 1424-1435

39 Shi S S. Morphology study on the human tooth deformity and cranial jaw in 2200 years ago unearthed in Xi' an areas (in Chinese). Master Dissertation. Xi' an: The Fourth Military Medical University, 2013 [石飒飒. 西安地区出土 2200 年前人畸形牙内陷及颖领骨的形态学 研究. 硕士学位论文. 西安: 第四军医大学, 2013]

40 Zhou M, Li Y N. A preliminary study of human bones unearthed from Longkou tombs in Danjiang Reservior (in Chinese). Jianghan Archaeol, 2010, (4): 108-112 [周蜜, 李永宁. 丹江库区龙口墓群出土人骨的初步研究. 江汉考古, 2010, (4): 108-112]

41 Hou K, Wang M H, Zhu H. The biological archaeological study of human vertebra disease in Chifeng Xinglonggou ruins (in Chinese). J Anthropol, 2017, 36: 87-100 [侯㑆, 王明辉, 朱泓. 赤峰兴隆沟遗址人类椎骨疾病的生物考古学研究. 人类学学报, 2017, 36: 87-100]

42 Wei Q, Shi X J, Susan K, et al. An ancient case of human knee disease found in the Salausu river (in Chinese). Wen Wu Chun Qiu, 2011, (4): 15-19 [卫奇, 史小进, Susan K, 等. 萨拉乌苏河发现的人类膝关节病变古病例. 文物春秋, 2011, (4): 15-19]

43 Li F J, Zhu H. Pathological observation of the bones in the Neolithic age of Jiangjialiang from Yangyuan, Hebei (in Chinese). In: Conference on China Frontier Aachaeology, 2005 [李法军, 朱泓. 河北阳原姜家梁新石器时代居民骨骼的病理观察. 见: 中国边疆考古 学术讨论会论文, 2005]

44 Wang Y. The studies on relationships between physical character of Liangzhu ancestors and the social economy and environment-An analysis of the physical character of unearthed bones in Guangfulin, Songjiang District in Shanghai, a case (in Chinese). Cult Rel Southern China, 2014, (2): 177-180 [汪洋. 良渚先民的体质特征与经济、环境适应关系研究一以上海松江广富林遗址出土人骨的体质 人类学研究为例. 南方文物, $2014,(2): 177-180]$

45 Zhang J L, Chang E, Zhu H. New progress in studies on ancient bones across the century (in Chinese). J Liaoning Prov Museum, 2007, 178-189 [张敬雷, 常娥, 朱泓. 古人骨研究跨世纪的新进展. 辽宁省博物馆馆刊, 2007, 178-189]

46 Sooyeun L, Boyeon C, Jihyun K, et al. An LC-MS/MS method for the determination of five erectile dysfunction drugs and their selected metabolites in hair. J Chromatogr B, 2015, 978-979: 1-10

47 He Z J. A brief discussion about ancient pot of decocting and warming herbs (in Chinese). Sichuan Cult Rel, 1998, (3): 27-31 [和中浚. 略论古代謷药温药器. 四川文物, 1998, (3): 27-31]

48 He Z J. The research of medicinal mortar and the relationship between mortar and pestle (in Chinese). Sichuan Cult Rel, 1998, (6): 31-37 [和中浚. 药用用杵臼考——兼谈药用杵臼与乳钵的关系. 四川文物, 1998, (6): 31-37]

49 Zhou Y J, Zhang J Z. The application of drug residue analysis in archaeology (in Chinese). Cult Rel Southern Chin, 2011, (2): 158-163 [周昱君, 张居中. 药物残留物分析技术的考古学应用. 南方文物, 2011, (2): 158-163]

50 Evershed R P. Organic residue analysis in archaeology: The archaeological biomarker revolution. Archaeometry, 2008, 50: 895-924

51 Salih B, Sipahi T, Dönmez E O. Ancient nigella seeds from Boyali Hoyuk in north-central Turkey. J Ethnopharmacol, 2009, 124: $416-420$

52 You X L. Discussion on the origin, differentiation and propagation of cultivated rice based on unearthed paddy from hemudu sites (in Chinese). Acta Agron Sin, 1979, (3): 1-10 [游修龄. 从河姆渡遗址出土稻谷试论我国栽培稻的起源、分化与传播. 作物学报, 1979, (3): 1-10]

53 Sun Y G, Zhao Z J. The results and analysis of ruins flotation in Liao Dynasty from Bayan Tara, Chifeng, Inner Mongolia (in Chinese). Cult Rel Southern China, 2014, (3): 68-71 [孙永刚, 赵志军. 内蒙古赤峰巴彦塔拉辽代遗址浮选结果及分析. 南方文物, 2014, (3): 68-71] 


\title{
Bencao archaeology: A novel interdisciplinary field of herbal medicine and archaeology
}

\author{
Huasheng Peng ${ }^{1,2}$, Yuan Yuan ${ }^{2} \&$ Luqi Huang ${ }^{2 *}$ \\ ${ }^{1}$ School of Pharmacy, Anhui University of Traditional Chinese Medicine, Hefei 230012, China; \\ ${ }^{2}$ State Key Laboratory of Dao-di Herbs, NationalResource Center for Chinese Materia Medica, China Academy of Chinese Medical Sciences, \\ Beijing 100700, China \\ * Corresponding author, E-mail: huangluqi01@126.com
}

Traditional Chinese Medicine is a characteristic of ancient China. It is also an important feature of Chinese medicine and archaeology. Traditional Chinese pharmacology is called "Bencao". Therefore, research on archaeologically unearthed drugs or medicine-related sites and relics is called Bencao archaeology. Bencao archaeology is a field of research on medicine-related archaeological sites and relics. The common goals of Bencao archaeology and archaeology in general are to understand the history of ancient human beings and how they prevented and treated diseases. The culture of Traditional Chinese Medicine is extensive and profound, and it has a long history. With the growth and development of archaeology in the twentieth century, many drugs or drug-related ruins (remains) have been unearthed, laying a solid foundation for carrying out Bencao archaeological research. Bencao archaeology applies modern archaeological theories and research methods and explores the relationship between humans and drugs based on unearthed drugs or medicine-related sites and relics. The findings of such research help reconstruct the temporal and spatial framework of the cultural remains and the history of Traditional Chinese Medicine, uncovering the historical process of the development of Chinese medicine. Bencao archaeology reveals the origin and development of drugs, their formation and transformation, and their production process. The main part of Traditional Chinese Medicine is plant medicine. There is a close correspondence between Bencao archaeology and plant archaeology. Both conform with archaeology in general. They discuss ancient human culture, reconstruct ancient human lifestyle, and explain the development and process of human culture. However, there are several differences in research objects, research methods, and problems between the two. Unearthed drugs or medicine-related sites and relics are the research objects of bencao archaeology; for example, health equipment, medicine tools, drug measurement tools, medical documents, herbs, and other medicine-related sites and relics. On the other hand, the research objects of plant archaeology are plant remains unearthed from archaeological sites. With regard to several aspects mentioned in this paper, Bencao archaeology and plant archaeology have an interactive relationship; their characteristics intersect, and they promote and supplement each other. Bencao archaeology is a new field that integrates archaeology with herbalism. Its nature and foundation lie in both herbalism and archaeology. At present, this research field is still in its infancy, but it has broad prospects for development. We need solid archaeological evidence to actively promote the progress and development of this field. This paper expounds the new interdisciplinary field of Bencao archaeology from many aspects, such as its foundation, definition and subject orientation, objects of study, research direction, and relationship with other branches of archaeology, thus providing a novel research path to extensively study herbal medicines.

Bencao archaeology, herbal medicine, archaeology, interdisciplinary

doi: 10.1360/N972018-00187 